\title{
World Analysis of the Determinants of the Inequality in Health. Is the Measurement of Inequality Important?
}

\author{
IGNACIO AMATE-FORTES* \\ ALMUDENA GUARNIDO-RUEDA \\ AGUSTÍN MOLINA-MORALES \\ Department of Economics and Business \\ University of Almería, Almería, Spain
}

\author{
Review paper \\ UDK: 614:364.01 \\ doi: $10.3935 /$ rsp.v27i1.1600 \\ Received: September 2018
}

\begin{abstract}
This essay has a double aim. On the one hand, to identify what are the determinants in the inequality in health. On the other hand, to estimate to what extent the inequality indicator used is important. To do this, we use a cross-sectional model for 176 countries. The achieved results allow concluding that the choice of the inequality measurement is a key element in this type of studies. Also, inequality in income distribution, the weight of the rural population and capitalism make inequality in health increase.
\end{abstract}

Key words: health inequality, income inequality, institutions, women, health expenditure.

\section{INTRODUCTION}

Does inequality in health matter? The interest in studying health inequality has increased in the last decades, although there are not many comparative analyses among the countries of the determinants of this inequality in the literature. Also, there are many papers which focus more on the importance of the measurement of inequality in health rather than on analysing its causes because, as López-Casasnovas and Rivera (2002) assert, there is no complete and comparable health index among countries.

This research is intended for responding to a dual objective. On the one hand, it identifies the determinants of inequality in health, and on the other hand, we estimate how the model is affected by the measurement used for this inequality. In this sense, the indicators used in this work imply a novel aspect, since it is used in the Global Health Gap Index, which the World Vision International Organization elaborates, and the four indicators of inequality that compose this index. With these five indicators, inequality is measured globally, from the point of view of health output and inequality in health care, which allows to verify if the measurement of health inequality used affects the results of the estimates, distinguishing between those variables that measure health inequality from health outcomes and those that measure it from inputs. In order to analyze the causes of inequality, a cross-sectional model for 176 countries is estimated during the year 2013. Novel explanatory variables have been added to the traditional analysis of health inequality, such as the institutional variables that can

\footnotetext{
* Ignacio Amate-Fortes, Department of Economics and Business, University of Almería, Carretera Sacramento s/n 04120 La Cañada de San Urbano Almería Spain (ES), iamate@ual.es
} 
respond to what extent capitalism reduces or increases the inequality in health.

The results obtained allow answering the question stated in the title of this paper. The measurement of inequality matters since the results vary depending on the index used. Moreover, it can be concluded that the greater the inequality of income, the weight of the rural poverty and the degree of capitalism measured through the Index of Economic Freedom are, the greater the inequality in health is. On the other hand, a higher income per inhabitant, higher education of women and the increase on the public expenditure on health makes it decrease.

After this introduction, the second heading consists of a literature review of the main works carried out in this field. Subsequently, the model and the variables used are explained and a discussion of the results obtained is carried out. Finally, we present the main conclusions on the basis of the estimates carried out.

\section{THEORETICAL FRAMEWORK}

Since three decades ago, the interest to analyze health inequality has grown. However, there is a lack of comparative studies among countries because many of these works have primarily analyzed health surveys without developing a comparative analysis among the countries. In addition, the researchers have paid more attention to the study of the importance of the health inequality measurement rather than to analyzing its determinants, because there is no inequality health index which allows comparative studies among the countries (Lopez-Casasnovas and Rivera, 2002). Many authors have proposed different ways to measure this inequality, such as Flegg (1982), Le Grand (1985, 1987), Parkin et al. (1987), Pamuk (1988) and Leclere (1989) who used the mortality and the life expectancy indexes as health indicators, which allow comparative studies among the countries, but they do not reflect the improvements in quality of life (López-Casasnovas and Rivera, 2002). As a summary, Borrell et al. (2000) classified the different measurements of health inequality according to whether the socio-economic level in the analysis, the availability of individual or aggregated data, measurement of effect or total impact, and relative or absolute measurement were added.

More recently, Sahn and Younger (2009) use the BMI as a measurement of inequality in intra-household health. For their part, Tang et al. (2009) employ the variable "realization of potential life years" (age at death / potential length of life) to measure health inequality. An alternative perspective is offered by Ho and Slavov (2012) who, through the use of the life length as measurement of inequality, discover that it decreased during the last century despite the increase in the inequalities of income.

Regarding the works which address the study of the determinants of health inequality, the main explanatory variables used by the researchers are those which relate to income and distribution, education and inequality in health (Pamuk, 1988; Etner, 1996; Houweling et al., 2001; Marmot, 2005; Hernández and Jiménez, 2009; Chatterji et al., 2013; King et al., 2013; Nolan and Laite, 2014). Likewise, the size of public expenditure on health has been employed as a determining factor of health inequality (Pamuk, 1988).

Furthermore, gender studies have been carried out, such as those by Arber and Lahelma (1993) or by Borrell and Artazcoz (2008). On the other hand, Gatrell et al (2004) made a spatial analysis of inequality in health, showing how the geographical inequalities affect health outcomes.

Finally, other determinants that have been used in economic literature are the variables related to the labour market, that is to say, both the working conditions and 
the lack or not of employment (Dalghren and Whitehead, 1991), since labour risks and psychological stress affect the healthy lifestyle. In fact, the type of job has an impact on the esteem and social approval (Mackenbach and Bakker, 2002). Also, environmental variables have been used as a determinant of health inequality, such as the access to basic sanitation, clean water and waste disposal (Dalghren and Whitehead, 1991; WHO, 2009).

The intention here is to further deepen the analysis of the determinants of inequality in health through a comparative study of 176 countries by 2013 . The goal is a double one; on the one hand, it is to identify how important the indicator of inequality in health chosen is, and on the other hand to estimate the effect that different determinants of inequality in health have, introducing institutional variables as explanatory variables in this type of analysis.

\section{METHOD}

This work will adapt to the classic model of Dalghren and Whitehead (1991) to carry out a comparative analysis among 176 countries. For these two medical sociologists, the determining factors of health are grouped in concentric layers, from the structural determinants (outer layer) to the individual lifestyles (inner layer).

The model shows that the individuals' health status is affected not only by the age, sex and other genetic factors, but also by personal behavior and lifestyles. People with a bad economic situation tend to have an unhealthy lifestyle, such as smoking, alcohol abuse, drugs and poor nutrition. On the other hand, labour and environmental conditions, and access to basic services constitute another set of variables which determine the health status. Finally, the economic situation and the cultural and environmental conditions prevalent in a

Figure 1

The Dalghren-Whitehead model of determinants in health

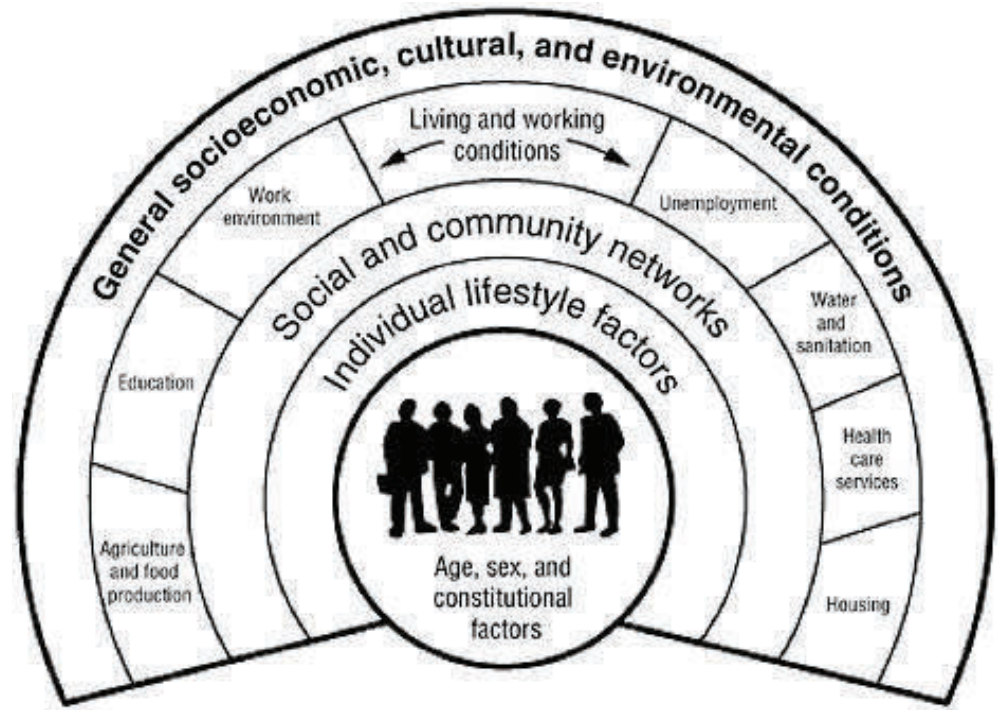

Source: Dalghren and Whitehead (1991). 
country will also affect the outcome on the health of its inhabitants.

\section{Data}

To perform this analysis a new indicator has been used, the Global Health Gap Index made by the Organization World Vision International (2013). This index, despite its very recent creation, has already been used in some works, such as in Madrid and Traisci-Marandola (2016). The Global Health Gap index aims to provide an overview on inequalities in health within countries and among countries. Through this index, inequality is measured in a global way. The Global Health Gap index is the result of adding four heterogeneous indicators, which allows checking if measuring the inequality from the point of view of health outcomes or health inputs (health care) affects the analysis of the determinants of the inequality in health. These indexes are the following:

- Inequality in Health-Adjusted Human Development Index. The Human Development Index (HDI) represents a national average of achievements in human development in three areas: health (life expectancy), education and income. As all the averages, it covers disparities in human development among the population of a country. Therefore, the adjusted HDI is used, which takes into account how such achievements in human development are distributed among the population. In this way, the greater the difference between the HDI and the adjusted HDI is, the greater the inequality within the country will be. In this precise case, the Global Health Gap index takes into account the health dimension of HDI, that is to say, it takes into account inequality in life expectancy. In this sense, the index used is the Inequality-Adjusted Life Expectancy Index which measures the inequality in the distribution of expected length of life based on data from inequality in life expectancy and the HDI life expectancy index. Therefore, this variable is used to measure the inequality in health from the point of view of output.

- Financing for health: out-of-pocket health expenditure as a percentage of the total health expenditure. In many countries, both rich and poor, the costs of health care can lead to a serious impoverishment. Out-of-pocket health payments are a key indicator for the health financing systems and they help to understand the weight the payments made directly by the families have in the health expenditure. The bigger the weight of these payments is, the more difficult the access to healthcare is and the bigger the impoverishment of the population is. Thus, out-of-pocket health expenditure is used as a variable which measures the inequality in health from the point of view of inputs.

- Health outcome: Infant Mortality Rate (IMR). The Global Health Gap index uses the Adolescent Fertility Rate (AFR) as a proxy indicator of the variable result in child health, so it is decided to use the Infant Mortality Rate because it describes child health better. IMR measures the probability of dying by the age of 5 per 1,000 live births. Like the Inequality in Health-Adjusted Human Development Index, this variable is used to measure health inequality from the scope of health outcomes.

- Coverage of health services. The total density of physicians, nurses and midwives per 1,000 people has been used as a proxy indicator of the coverage of health services. The relationship between the country's density of these health personnel and the average density of health personnel for that country's income grouping is used. Due to the lack of complete information about 
the density of health workers for all the countries, in the case of the countries with the lowest income, the number of the births which were assisted by skilled health personnel is employed. As explained in the case of the out-of-pocket health expenditure, this variable is used to measure health inequality from the point of view of health inputs.

The choice of the explanatory variables has been made according to the Dalghren and Whitehead (1991) model explain above, as well as the social determinants of health pointed out by the WHO (Wilkinson and Marmot, 2003). These authors include, among others, the following determinants of health: inequality in income distribution, poverty, education, general access to the health service through public health services, unemployment, consumption of certain addictive substances, such as alcohol, pollution and access to certain basic services, such as drinking water.

The set of dependent and explanatory variables used in this study can be summarized in the following table.

Table 1

Variable definitions and summary statistics

\begin{tabular}{|c|c|c|c|c|c|c|}
\hline Variable & Description & Obs. & Mean & Std. Dev. & Min & Max \\
\hline $\begin{array}{l}\text { Global Health } \\
\text { Gap Index }\end{array}$ & $\begin{array}{l}\text { Index of inequality in health. Source: } \\
\text { World Vision International. }\end{array}$ & 176 & 264.08 & 109.80 & 46 & 518 \\
\hline $\begin{array}{l}\text { Inequality } \\
\text { in Health- } \\
\text { Adjusted HDI }\end{array}$ & $\begin{array}{l}\text { The inequality in distribution of } \\
\text { expected length of life. Sources: Human } \\
\text { Development Report (2013), UNDP. }\end{array}$ & 176 & 64.09 & 41.15 & 1 & 141 \\
\hline $\begin{array}{l}\text { Out-of- } \\
\text { pocket health } \\
\text { expenditure }\end{array}$ & $\begin{array}{l}\text { Out-of-pocket health expenditure } \\
\text { as a percentage of the total health } \\
\text { expenditure. Fuentes: World Health } \\
\text { Statistics } 2013 \text { report; } 2012 \text { country } \\
\text { profiles from Countdown to } 2015 \text {. }\end{array}$ & 176 & 77.73 & 45.09 & 1 & 157 \\
\hline $\begin{array}{l}\text { Infant Mortality } \\
\text { Rate }\end{array}$ & $\begin{array}{l}\text { Under-five mortality rate as the } \\
\text { probability of dying by age } 5 \text { per } 1,000 \\
\text { live births. Source: WHO. }\end{array}$ & 176 & 34.41 & 33.84 & 2 & 167.1 \\
\hline $\begin{array}{l}\text { Coverage of } \\
\text { health services }\end{array}$ & $\begin{array}{l}\text { The country's density of physicians, } \\
\text { nurses and midwives per } 1,000 \text { people } \\
\text { in relation to the same variable for that } \\
\text { country's income grouping; and the } \\
\text { births which were assisted by skilled } \\
\text { health personnel. Sources: World Health } \\
\text { Statistics } 2013 \text { report; } 2012 \text { country } \\
\text { profiles from Countdown to } 2015 \text {. }\end{array}$ & 176 & 67.32 & 34.58 & 1 & 125 \\
\hline Gini Index & $\begin{array}{l}\text { Income distribution inequality } \\
\text { index. Sources: World Development } \\
\text { Indicators, World Bank; CIA Factbook. }\end{array}$ & 175 & 39.20 & 9.04 & 24.82 & 65.02 \\
\hline $\begin{array}{l}\text { GDP per } \\
\text { capita }\end{array}$ & $\begin{array}{l}\text { GDP per capita based on purchasing } \\
\text { power parity (PPP) in constant } \\
\text { international \$. Source: World } \\
\text { Development Indicators, World Bank. }\end{array}$ & 176 & 16972.52 & 19008.63 & 584.38 & 127562.2 \\
\hline $\begin{array}{l}\text { Public health } \\
\text { expenditure }\end{array}$ & $\begin{array}{l}\text { The public health expenditure as } \\
\text { a percentage of the total health } \\
\text { expenditure. Source: World } \\
\text { Development Indicators, World Bank. }\end{array}$ & 175 & 58.13 & 18.56 & 16.57 & 96.19 \\
\hline
\end{tabular}


Table 1. Continued

\begin{tabular}{|c|c|c|c|c|c|c|}
\hline Variable & Description & Obs. & Mean & Std. Dev. & Min & Max \\
\hline Poverty & $\begin{array}{c}\text { Percentage of population living } \\
\text { below poverty line. Sources: World } \\
\text { Development Indicators, World Bank; } \\
\text { CIA Factbook. }\end{array}$ & 151 & 29.72 & 21.97 & 0 & 87.72 \\
\hline Education & $\begin{array}{l}\text { Percentage of women to men enrolled } \\
\text { at tertiary level in public and private } \\
\text { schools. Source: World Development } \\
\text { Indicators, World Bank } \\
\end{array}$ & 136 & 113.88 & 64.95 & 23.90 & 676.16 \\
\hline Unemployment & $\begin{array}{c}\text { Total unemployed people as a } \\
\text { percentage of the total labour force. } \\
\text { Source: World Development Indicators, } \\
\text { World Bank. }\end{array}$ & 167 & 8.65 & 5.99 & 0.3 & 31 \\
\hline Rural water & $\begin{array}{l}\text { Percentage of the rural population using } \\
\text { an improved drinking water source. } \\
\text { Source: World Development Indicators, } \\
\text { World Bank. }\end{array}$ & 168 & 8.65 & 5.99 & 0.3 & 31 \\
\hline $\mathrm{CO}^{2}$ & $\begin{array}{c}\mathrm{CO}^{2} \text { emissions (metric tons per capita). } \\
\text { Source: World Development Indicators, } \\
\text { World Bank. }\end{array}$ & 176 & 4.72 & 6.42 & 0.01 & 40.31 \\
\hline $\begin{array}{l}\text { Life } \\
\text { expectancy }\end{array}$ & $\begin{array}{l}\text { Life expectancy at birth. Source: World } \\
\text { Development Indicators, World Bank. }\end{array}$ & 176 & 70.09 & 9.30 & 45.33 & 83.10 \\
\hline Physicians & $\begin{array}{l}\text { Total density of physicians per } 1,000 \\
\text { people. Source: World Development } \\
\text { Indicators, World Bank. }\end{array}$ & 155 & 1.69 & 1.53 & 0.01 & 7.74 \\
\hline $\begin{array}{l}\text { Population } \\
\text { density }\end{array}$ & $\begin{array}{l}\text { People per sq. Km of land area. Source: } \\
\text { World Development Indicators, World } \\
\text { Bank. }\end{array}$ & 176 & 184.29 & 613.97 & 1.83 & 7713.14 \\
\hline $\begin{array}{l}\text { Rural } \\
\text { population }\end{array}$ & $\begin{array}{c}\text { People living in rural areas as a } \\
\text { percentage of total population. Source: } \\
\text { World Development Indicators, World } \\
\text { Bank. }\end{array}$ & 176 & 43.75 & 23.15 & 0 & 91.33 \\
\hline Parliamentary & $\begin{array}{l}\text { Percentage of parliamentary seats in a } \\
\text { single or lower chamber held by women. } \\
\text { Source: World Development Indicators, } \\
\text { World Bank. }\end{array}$ & 172 & 19,93 & 11.50 & 0 & 63.8 \\
\hline Crime & $\begin{array}{l}\text { Number of homicides for each } 100,000 \\
\text { habitants. Fuente: United Nation Office } \\
\text { on Drugs and Crime. }\end{array}$ & 162 & 9.54 & 13.16 & 0.31 & 91.61 \\
\hline Alcohol & $\begin{array}{l}\text { Rate of alcohol consumption per capita } \\
\text { (Litres consumed by person and year). } \\
\text { Source: Global Health Observatory Data } \\
\text { Repository, World Health Organization. }\end{array}$ & 173 & 4.91 & 3.81 & 0 & 14.37 \\
\hline Globalization & $\begin{array}{c}\text { KOF Globalization Index. It measures } \\
\text { the global connectivity, integration and } \\
\text { interdependence of countries in cultural, } \\
\text { ecological, economic, political, social } \\
\text { and technological spheres. Source: KOF, } \\
\text { ETH Zurich. }\end{array}$ & 175 & 57.66 & 16.60 & 25.43 & 92.17 \\
\hline
\end{tabular}


Table 1. Continued

\begin{tabular}{|c|c|c|c|c|c|c|}
\hline Variable & Description & Obs. & Mean & Std. Dev. & Min & Max \\
\hline Democracy & $\begin{array}{l}\text { Voice and Accountability. Index } \\
\text { belonging to the Aggregate Governance } \\
\text { Indicators which measures the degree } \\
\text { to which a country's citizens can take } \\
\text { part in the election of their government } \\
\text { plus freedom of speech, freedom } \\
\text { of association and freedom of the } \\
\text { press. Source: Worldwide Governance } \\
\text { Indicators, World Bank. }\end{array}$ & 176 & 46.32 & 28.40 & 0.95 & 100 \\
\hline Capitalism & $\begin{array}{l}\text { Economic Freedom Index. It includes } \\
\text { evaluations of trade policies, } \\
\text { Government tariffs, Government } \\
\text { intervention in the economy, monetary } \\
\text { policy, flow of capital and foreign } \\
\text { investment, foreign activity, financial } \\
\text { activity, price and wage control, property } \\
\text { rights and black market activity and } \\
\text { regulation. Source: Heritage Foundation/ } \\
\text { Wall Street Journal. }\end{array}$ & 166 & 59.78 & 10.55 & 28.5 & 88 \\
\hline
\end{tabular}

Source: Compiled by authors.

\section{The model}

As it has commented above, the model of Dalghren and Whitehead (1991) has been adapted to analyze the determinants of inequality in health using a cross-sectional model for 176 countries during the year 2013. The model used is as follows:

INEQUALITY $_{\mathrm{i}}=\beta_{1}$ GINI $_{\mathrm{i}}+\beta_{2}$ GDPPC $_{\mathrm{i}}+$ $\beta_{3}$ POVERTY $_{\mathrm{I}}+\beta_{4} \mathrm{CO}_{\mathrm{i}}+\beta_{5}$ DENSITY $_{\mathrm{i}}+$ $\beta_{6}$ RURALPOP $_{\mathrm{i}}+\beta_{7}$ PARLIAMENTARY $_{\mathrm{i}}$ $+\gamma_{1}$ PHEXPENDITURE $_{i}+$

$\gamma_{2}$ PHYSICIANS $_{\mathrm{i}}+\gamma_{3}$ EDUCATION $_{\mathrm{i}}$

$+\gamma_{4}$ UNEMPLOYMENT $_{\mathrm{i}}+$

$\gamma_{5}$ RURALWATER $_{\mathrm{i}}+\delta_{1}$ CRIME $_{\mathrm{i}}$

$+\delta_{2}$ GLOBALISATION $_{\mathrm{i}}+$

$\delta_{3}$ DEMOCRACY $_{\mathrm{i}}+\delta_{4}$ CAPITALISM $_{\mathrm{i}}+$ $\theta_{1} \mathrm{ALCOHOL}_{\mathrm{i}}+\lambda_{1} \mathrm{LE}_{\mathrm{i}}+\mu_{\mathrm{i}}$

where, INEQUALITY refers to the inequality in health, as mentioned above. Five different variables have been used in order to analyze to which point the inequality measure chosen alters the model. The five measures of inequality are the Global Health Gap Index, the difference between the HDI and the adjusted HDI in the field of health, the out-of-pocket health expenditure in relation to the total expenditure on health, the adolescent fertility on the average of adolescent fertility of the group income of the country in question, and the density of physicians, nurses and midwives per each 1,000 inhabitants on the average density of the health personnel of the Group's income of the country concerned. GINI is the indicator of inequality in the distribution of income; GDPPC is the per capita GDP measured in PPP terms in constant \$; POVER$T Y$ measures the percentage of population below the poverty line; $\mathrm{CO}^{2}$ accounts for $\mathrm{CO}^{2}$ emissions and it is a proxy variable of the environmental conditions of the country in question; DENSITY measures population density; RURALPOP represents the percentage of population living in rural areas in population; PARLIAMENTARY 
measures the percentage of women who are parliamentary and it is a proxy variable of the role of women in the society of the country in question; PHEXPENDITURE is the public health expenditure on the total expense on health; PHYSICIANS measures the number of physicians per 1,000 inhabitants; EDUCATION is a proxy variable for the educational level of women in the country in question through the ratio between the number of women at university and the total number of men enrolled; $U N$ EMPLOYMENT is the unemployment rate; RURALWATER reflects the percentage of population with access to safe water in rural areas; $C R I M E$ is the number of homicides for each 100,000 inhabitants; GLOBALIZA$T I O N$ is the KOF Index of Globalization; $D E M O C R A C Y$ is the Voice and Accountability Index; CAPITALISM is the Index of Economic Freedom; ALCOHOL is a proxy variable of the lifestyle of the citizens of the country in question and it is represented by the rate of alcohol consumption per capita; $L E$ is the life expectancy and it is a proxy variable of the health status of the population by the simple fact of being born and living in the country in question; and $\mu \mathrm{i}$ is the error term.

\section{RESULTS}

The model has been estimated by Ordinary Least Squares (OLS) and by Two Stage Least Squares (2SLS) to avoid the possible endogeneity among some of the selected variables. In fact, a collinearity analysis has been performed that it ruled out the existence of significant correlations between the explanatory variables. Likewise, an analysis of the Variance Inflation Factor (VIF) has been carried out, through which a possible multicollinearity problem has been detected that has not been confirmed by the robustness analysis. Nevertheless, the model has been estimated by 2SLS which instruments the variable suspected of generating the problems of multicollinearity (GDPpc) and, after performing the relevant tests of over-identification of the instruments and the test $\mathrm{C}$ of endogeneity of the instruments, the variables $\mathrm{CO}^{2}$, education and rural water have been used as instruments, and the life expectancy variable has been dropped because it presents an endogeneity problem with the other instruments. Also, it has been checked the non-existence of heteroscedasticity through the Breusch-Pagan test when the Global Health Gap index, out-of-pocket expenditure, infant mortality rate and health personnel are used as dependent variables. In the other two cases, the problem of heteroscedasticity has been solved using the robust estimator in each case. Finally, the global significance of the model has been verified.

Ten different estimates were undertaken according to the five variables of health inequality used and the two estimators employed. The empirical results are collected in the following table. 


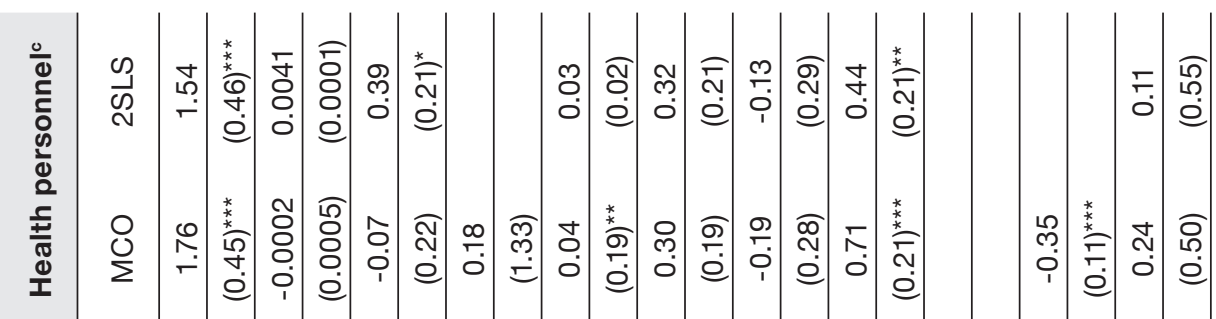

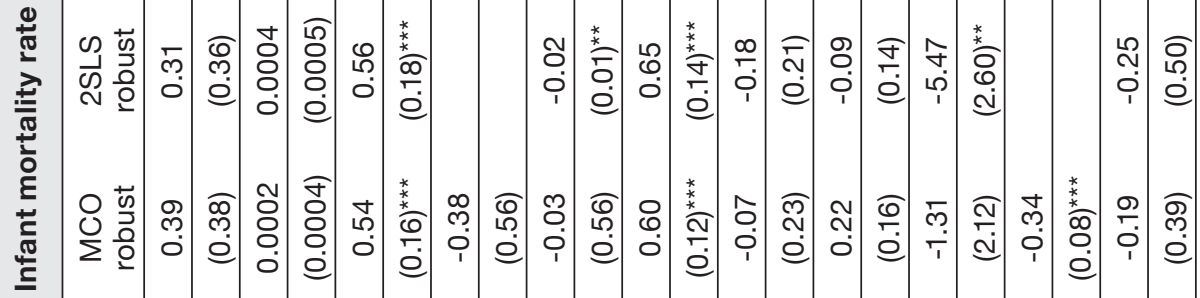

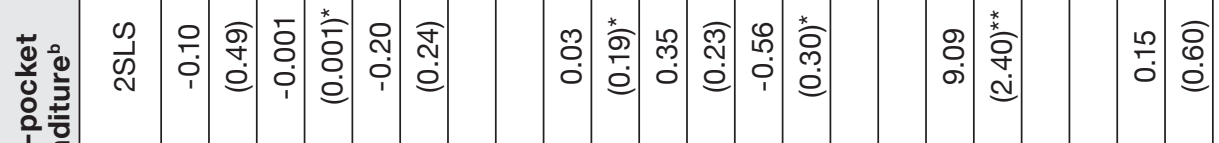

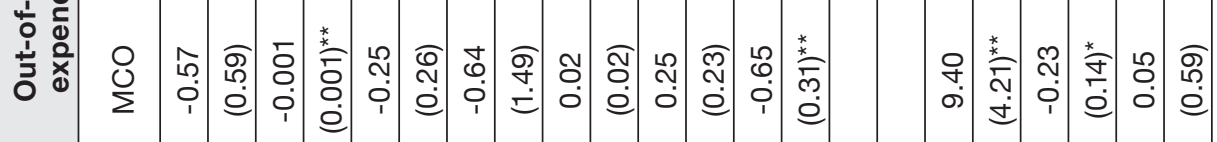

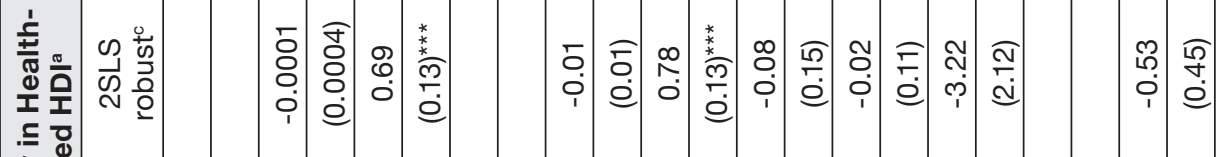

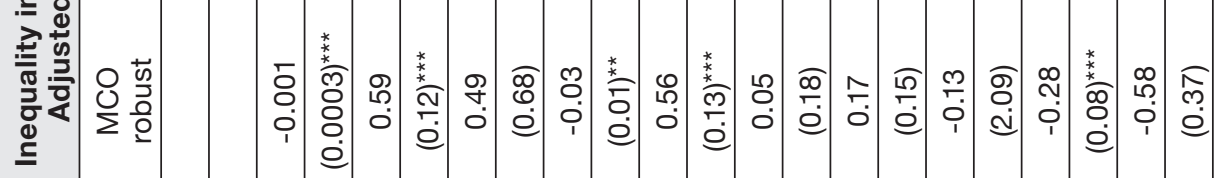

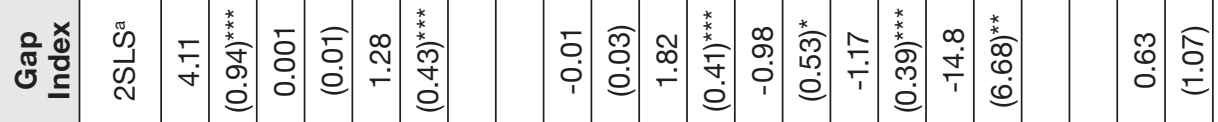

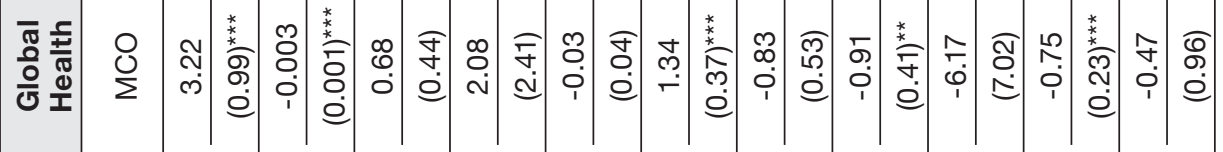

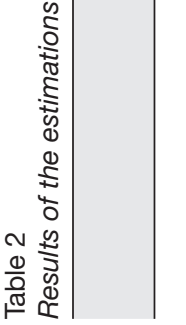

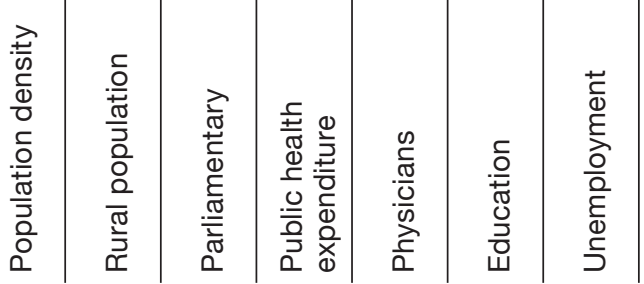




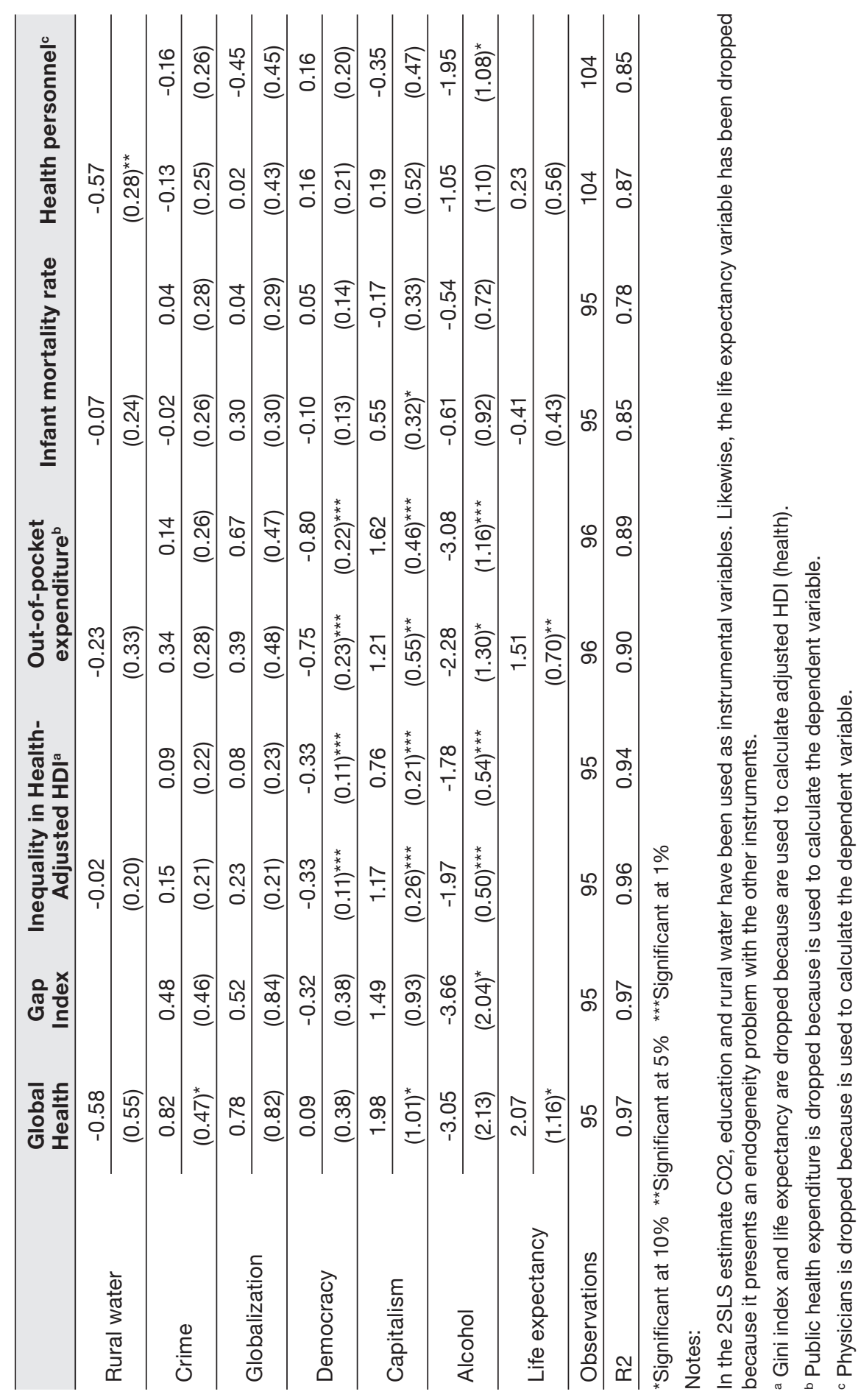


The results achieved on the 10 estimates made firstly show that the model is robust since significant changes have been barely appreciated in the sign of the regressors estimated or in the significance of them regarding the estimation method used. In addition, the quality of adjustment is very good since $\mathrm{R}^{2}$ does not decrease less than 0.78 in any of the estimates. However, the effect that each of the explanatory variables has on inequality in health varies, both in its sign and in its significance regarding the inequality measurement chosen, so that the choice of the indicator of inequality in health is a key factor in this kind of analysis.

Many authors have pointed out that, more than absolute income, it is the difference of income which determines to a greater extent the inequality in health (Duleep, 1995; Wilkinson, 1996; Deaton, 1999). In this study, this fact is corroborated since the Gini index is significant when using the Global Health Gap index and the lack of health personnel is used as a dependent variable. In these cases, inequality in the distribution of income has a positive and significant effect on health inequality, that is to say, in the countries where income inequality is greater, health inequality is also more marked. However, the effect of absolute income measured by per capita GDP is negative and significant in all estimates, except when the lack of health workers and infant mortality rate are used as measurements of health inequality. This means that the richest countries suffer a lower inequality in health, although, as López-Casasnovas and Rivera (2002) conclude, the significance of the estimated parameter depends on the indicator we use for health inequality.

Poverty shows a positive effect on almost all the dependent variables used. Thus, there is a positive relationship between both variables when we take into account the inequality in health through the Global Health Gap index, the Human Development Index, the infant mortality rate and the lack of health personnel. In these cases, this result coincides with that obtained by Anand and Ravaillon (1993). However, the relationship becomes negative, but not significant when using the out-of-pocket health expenditure in relation to the total expenditure on health as a measurement of health inequality. This implies that the poorer the country is, the less is the possibility that the population incurs this kind of expenses, therefore, in this precise case, poverty reduces inequality. Probably, the relationship is the other way around, that is to say, when the population is forced to pay for healthcare from the family budget, they become impoverished.

In the majority of cases, the social, cultural, demographic, and environmental conditions show the expected results. Thus, the population density has a negative relationship with health inequality. The countries whose population density is higher have lower levels of inequality when these are measured through the Human Development Index and the infant mortality rate. On the other hand, density positively affects inequality in health when the lack of health personnel and the out-of-pocket expenditure are used as indicators. This is due to the fact that in order to calculate this index of inequality the number of health workers per 1,000 inhabitants is taken into consideration, so it seems logical that the greater the population density is, the more difficult will it be for the country to provide the entire population with appropriate healthcare. Likewise, a greater population density will more likely increase private health spending. However, the effect that the weight of the rural population has on the inequality in health is more significant. The positive and significant sign in the majority of estimates suggests that in less developed countries, where the rural population is more important, health inequality is greater. It shows, as López-Casasnovas and Rivera pointed out 
(2002), that the inequality in the access and availability of healthcare resources affects the inequality in health.

Also, this research is intended for studying how the role of women affects the inequality in health. To do so, the weight that women have in the Parliament has been used as a proxy variable. The negative and significant sign for two of the dependent variables employed shows that the role of women in society is an important variable when analyzing health inequality. In this way, the greater the importance of women in the countries is, the lesser the inequality in health is. In addition, women's education is essential to reduce health inequality, primarily among the minors. The negative and significant sign estimated for this variable allows saying that the bigger the education of younger women is, the lesser the inequality in child health is. This result is in line with those obtained by Chaterji et al. (2013) in their analysis of inequality in health in America and Nolan, and with those obtained by Laite (2014) in the case of child health inequality in Ireland.

In terms of public health expenditure, the effect is as expected, except when the lack of health personnel is taken into account as a measurement of inequality. Thus, the significant and negative sign indicates that the bigger the public intervention in health is, the lower the inequality, in other words, the public sector reduces health inequality. It allows us to assert that those countries that give greater importance to the public health system obtain better results in health equity. This result coincides with that obtained by Wagstaff and Van Doorsaler (1993). On the contrary, the effect of this variable on inequality becomes positive when the lack of health staff is used. This result can, surprisingly a priori, be explained because the relationship between both variables goes in the opposite direction, that is to say, it is the lack of health workers that motivates governments to spend more on health and thus mitigate this deficit. Something similar happens with the explanatory variable that measures the number of physicians there is in the country in question. The effect of this variable on the inequality is only significant when we use the importance of the out-of-pocket payments above the total expenditure on health. In this case, the sign is positive, so the greater the number of physicians, the higher the out-of-pocket payment and, therefore, the bigger the inequality. This surprising result could be explained in the same way as we have explained above, that is to say, the relationship between the two variables is the opposite. Higher out-of-pocket health expenditure encourages medical qualification.

The environmental variable used cannot support any significant results, such as $\mathrm{CO}^{2}$ emissions. In other words, pollution does not cause greater inequality in health. We arrived to the same conclusion in the case of the unemployment variable. The lack of employment does not affect inequality in health. Essential infrastructures do not play a fundamental role in health inequality either. Even so, the negative and significant sign in one of the five estimates made for the variable that measures the percentage of rural population having access to drinking water allows us to affirm that an improvement in the living conditions of the rural population reduces inequality in health.

Regarding the effect of the institutional variables included in the model, it can be concluded that capitalism, measured by the economic freedom index, affects inequality positively. The positive and significant sign in most cases indicates that the lower the participation of the State in the economy and the greater individual freedom of the person are, the bigger the inequality in health is. Therefore, economic liberalism leads to greater health inequality. This is not to say that the capitalist system is an ob- 
stacle to the fight against health inequality, but that public sector intervention is essential to achieve this goal. Democracy, on the other hand, has the opposite effect, since it reduces health inequality, basically, when we take into account the Human Development Index and private health spending as measurements of inequality. Finally, globalization has no significant effect.

The crime rate has a positive, but very little significant effect on health inequality, in other words, in those countries where the homicide rate is greater, inequality is also more marked. Concerning the population's lifestyle, the alcohol consumption throws a priori surprising result. The negative sign indicates that the greater the consumption of alcohol per capita is, the lower the inequality in health is. This is due to a positive relationship between per capita GDP and per capita alcohol consumption, that is to say, in the richest countries the rate of alcohol consumption is higher (WHO, 2007) and, therefore, the inequality in health is lower. Finally, life expectancy has a direct relationship with health inequality when using the Global Health Gap index and the weight of the out-of-pocket health expenditure over the total expenditure on health as measurements of inequality. This shows that there is a positive relationship of causality between the absolute health index and the relative one. In other words, an improvement in the overall health of the population does not imply that it is evenly distributed among the population.

\section{CONCLUSIONS}

This study pursued a double objective. On the one hand, to identify the determinants of inequality in health, and on the other hand, to estimate to which extent the model is being affected by the use of one or another measurement of inequality in health. The results obtained show that the choice of the indicator of inequality is in- deed a key element when carrying out this type of studies, since the sign and, especially, the significance of the estimated parameters vary depending on the five measures used as dependent variables. Therefore, the results obtained depend on whether inequality is measured in global terms, or from the point of view of output or inputs in health.

One of the issues that has given rise to more discussion on the determinants of health and inequality in health among researchers is whether absolute income or relative income is more important. In accordance with the results of the estimates, it is verified that there is a direct relationship between inequality in the distribution of income and inequality in health. However, it is also true that health inequality decreases as the income of the country increases. For this reason, redistributive policies, the fight against poverty and the promotion of economic growth should be essential elements in any health equity plan. To achieve this, public intervention through health spending is necessary. The free market, private management, individualism, ultimately, capitalism does not reduce health inequality and it is necessary to combine the advantages offered by the market with the virtues associated with the intervention of the public sector, especially in the sectors as sensitive as healthcare. Healthcare is a merit good, with strong positive externalities that should be taken into account when setting up a country's healthcare system. Reducing health inequalities requires that the entire population has access to healthcare. However, in many countries there is a part of the population, such as those living in rural areas, for whom access to healthcare is more difficult, increasing the inequality in health between the rural and urban population.

Finally, gender discrimination must be fought. The results obtained show that the more important the role of women in soci- 
ety and the greater the education of women are, the less unequal the health is, primarily child health, since children's health is closely related to the working, economic and cultural situation of their mothers.

\section{REFERENCES}

Anand, S., \& Ravallion, M. (1993). Human development in poor countries: On the role of private incomes and public services. Journal of Economic Perspectives, 7(1), 133-150. https://doi. org/10.1257/jep.7.1.133

Arber, S., \& Lahelma, E. (1993). Inequalities in men's and women's ill-health: Britain and Finland compared. Social Science and Medicine, 37(8), 1055-1068. https://doi.org/10.1016/02779536(93)90440-F

Borrell,C., \& Artazcoz,L. (2008). Las desigualdades de género en salud: Retos para el futuro. Revista Española de Salud Pública, (82), 245-249. https:// doi.org/10.1590/S1135-57272008000300001

Borrell, C., Ru, M., Pasar, M. I., Benach, J., \& Kunst, A. E. (2000). La medición de las desigualdades en salud. Gaceta Sanitaria, 14(3), 20-33.

Chatterji, P., Lahiri, K., \& Song, J. (2013). The dynamics of income-related health inequality among American children. Health Economics, 22(5), 623-629. https://doi.org/10.1002/hec.2823

Dalghren, G., \& Whitehead, M. (1991). Policies and strategies to promote social equity in health. Stockholm: Institute for Future Studies.

Deaton, A. (1999). Inequalities in income and inequalities in health. NBER Working Paper, W741. Cambridge.

Duleep, H. O. (1995). Mortality and income inequality among economically developed countries. Social Security Bulletin, 58(2), 34-50. Available at https://www.ssa.gov/policy/docs/ssb/v58n2/ v58n2p34.pdf

Etner, S. L. (1996). New evidence on the relationship between income and health. Journal of Health Economics, 15(1), 67-85. https://doi. org/10.1016/0167-6296(95)00032-1

Flegg, A. T. (1982). Inequality of income, illiteracy and medical care as determinants of infant mortality in underdeveloped countries. Population Studies, 36(3), 441-458. https://doi.org/10.1080/ 00324728.1982.10405597

Gatrell, A., Popay, J., \& Thomas, C. (2004). Mapping the determinants of health inequalities in social space: Can Bourdieu help us?. Health and Space,
10(3), 245-257. https://doi.org/10.1016/j.healthplace.2003.09.005

Hernández, C., \& Jiménez, D. (2009). Las diferencias socioeconómicas en salud entre la población Española y extranjera en España: Evidencia de la encuesta nacional de salud. Gaceta Sanitaria, 23(1), 47-52.

Ho, B., \& Slavov, S. N. (2012). An alternative perspective on health inequality. Economics Bulletin, 32(4), 3182-3196. Available at https://ssrn.com/ abstract $=2209952$

Houweling, T., Kunst, A., \& Mackenbach, J. (2003). Measuring health inequality among children in developing countries: Does the choice of the indicator of economics status matter? International Journal for Equity in Health, (2), 1-12. https:// doi.org/10.1186/1475-9276-2-8

King, N. B., Haroer, S., \& Young, M. E. (2013). Who cares about health inequalities? Cross-country evidence from the World Health Survey. Health Policy and Planning, 28(5), 558-571. https://doi. org $/ 10.1093 /$ heapol/czs094

Le Grand, J. (1985). Inequalities in health: The human capital approach. Discussion Paper, 1. London School of Economics.

Le Grand, J. (1987). Inequalities in health: Some international comparisons. European Economic Review, 31(1-2), 182-191. https://doi. org/10.1016/0014-2921(87)90030-4

Leclere, A. (1989). Differential mortality by cause of death: Comparison between selected European countries. In J. Fox (Ed.), Health Inequalities in European Countries. Aldershot: Gower.

López-Casasnovas, G., \& Rivera, B. (2002). Las políticas de equidad en salud y las relaciones entre renta y salud. Hacienda Pública Española, 161(2), 99-126.

Mackenbach, J., \& Bakker, M. (2002). Reducing inequalities in health: A European perspective. London: Routledge.

Madrid, B. J., \& Traisci-Marandola, D. (2016). Child's right to health, education and freedom from hunger. In S. Deb (Ed.), Child Safety, Welfare and Well-being. Issues and Challenges (pp. 117-140). New Delhi: Springer India.

Marmot, M. (2005). Social determinants of health inequalities. The Lancet, 365(9464), 1099-1104. https://doi.org/10.1016/S01406736(05)71146-6

Nolan, A., \& Layte, R. (2014). Socio-economic inequalities in child health in Ireland. The Economic and Social Review, 45(1), 25-64. Available at https://www.esr.ie/article/view/107 
World Health Organization. (2007). Comité de Expertos de la OMS en Problemas Relacionados con el Consumo de Alcohol. OMS, Serie de Informes Técnicos, 944. Available at https://www. who.int/substance_abuse/expert_committee_alcohol_trs944_spanish.pdf

World Health Organization. (2009). Subsanar las Desigualdades en una Generación. Informe de la Comisión de Determinantes Sociales en Salud. Buenos Aires: OMS.

Pamuk, E. R. (1988). Social-class inequality in infant mortality in England and Wales from 1921 to 1980. European Journal of Population, (4), 1-21. https://doi.org/10.1007/BF01797104

Parkin, D., McGuire, A., \& Yule, B. (1987). Aggregate health care expenditures and national income. Is health care a luxury good?. Journal of Health Economics, 6(2), 109-127. https://doi. org/10.1016/0167-6296(87)90002-6

Sahn, D. E., \& Younger, S. D. (2009). Measuring intra-household health inequality: Explorations using the Body Mass Index. Health Economics, 18(S1), 13-36. https://doi.org/10.1002/hec.1459

Tang, K. K., Petrie, D., \& Prasada Rao, D. S. (2009). Measuring health inequality with realization of potential life years. Health Economics, 18(S1), 555-575. https://doi.org/10.1002/hec.1461

Wagstaff, A., \& Van Doorsaler, E. (1993). Equity in the delivery of health care: Methods and findings. In E. van Doorsaler, A. Wagstaff \& F. Rutten (Eds.), Equity in the Finance and Delivery of Health Care: An International Perspective. Oxford: Oxford University Press.

Wilkinson, R. (1996). Unhealthy societies: The afflictions of inequality. London: Routledge.

Wilkinson, R., \& Marmot, M. (2003). Social determinants of health. The sold facts. Copenhagen: World Health Organization.

World Vision International. (2013). The killer gap. A Global Index of health inequality for children. Available at http://www.wvi.org/thekillergap 


\title{
Sažetak
}

\section{SVJETSKA ANALIZA ODREDNICA NEJEDNAKOSTI U ZDRAVSTVU. JE LI MJERENJE NEJEDNAKOSTI VAŽNO?}

\author{
Ignacio Amate-Fortes, Almudena Guarnido-Rueda, Agustín \\ Molina-Morales
}

Departamento de Economía y Empresa,Universidad de Almería

Almería, Spain

Ovaj esej ima dvostruki cilj. S jedne strane, identificirati što su odrednice u nejednakost u zdravstvu. S druge strane, procijeniti u kojoj je mjeri pokazatelj nejednakosti važan. Da bismo to učinili, koristimo model poprečnog presjeka za 176 zemalja. Dobiveni rezultati omogućuju zaključivanje da je izbor mjerenja nejednakosti ključan element u ovom tipu studija. Također, nejednakost u raspodjeli dohotka, udio seoskog stanovništva i kapitalizam uzrokuju povećavanje nejednakosti u zdravstvu.

Ključne riječi: nejednakost u zdravstvu, dohodovna nejednakost, institucije, žene, izdaci za zdravstvo. 